\author{
Kinga Przybysz-Polakowska \\ Collegium Da Vinci \\ ORCID: 0000-0001-7648-4986
}

\title{
Facebook jako narzędzie komunikacji $z$ fanami. Analiza porównawcza aktywności pisarek: Katarzyny Bondy i Katarzyny Puzyńskiej
}

\begin{abstract}
Streszczenie
Artykuł zawiera prezentację oraz analizę wyników badań (zarówno jakościouych, jak i ilościouych) przeprowadzonych latem 2019 roku na facebookowych profilach pisarek Katarzyny Bondy i Katarzyny Puzyńskiej. Duumiesięczny monitoring profili dostarczył cennych danych, które umożliwiły weryfikację hipotez badawczych. Autorka założyła, że „wezwania do akcji” kierowane przez pisarki będą pozytywnie upływały na liczbę reakcji ze strony publiczności oraz że obie pisarki będą dodawać posty z podobną częstotliwością. Okazało się, że „wezwania do akcji” nie są tak istotne w komunikacji z fanami, jak mogłoby się to intuicyjnie uydawać. Dodatkowo wykryto znaczne różnice u zakresie częstotliwości dodawania postów: Katarzyna Puzyńska była zdecydowanie bardziej aktywna, a na jej koncie pojawiały się różnorodne posty, które można przyporządkować do czterech kategorii (autoportrety, promocje książek, natura, inne). W przypadku Katarzyny Bondy postów było znacznie mniej i można je podzielić na dwie zasadnicze kategorie (posty promujące książki oraz osobiste). Jednocześnie spostrzeżono, że obie pisarki chętnie wchodziły w interakcje z fanami, wykorzystując potencjał nouych mediów.
\end{abstract}

Słowa kluczowe: analiza mediów, Facebook, komunikacja w nouych mediach, pisarze w nouych mediach, komunikacja z fanami.

\section{Facebook as a communication tool with fans. A comparative analysis of Katarzyna Bonda and Katarzyna Puzyńska activity}

Article includes a presentation and analysis of research (both qualitative and quantitative) conducted during 2019 summer on Facebook profiles that belong to Katarzyna Bonda and Katarzyna Puzyńska. Two-months monitoring of their profiles has delivered valuable data that enabled the verification two hypotheses. The Author assumed, that writer's "call to action" phrases would positively influence fans' reactions. The Author also assumed that both writers would publish posts at the same pace. It turned out that call-to-action phrases are not that important in relationships with fans as one could expect. In addition, major differences between publication frequencies were discovered: Katarzyna Puzyńska was definitely more active. She published more diverse posts, that could be grouped in 4 categories (self-portraits, books' promotion, nature, other). In Bonda case posts could be grouped into two categories (books' promotion and personal ones). It was also noticed that both writers eagerly interacted with their fans using the potential that new media have. 
Keywords: media analysis, Facebook, communication in new media, writers in new media, communication with fans.

\section{Wstęp: przesłanki do podjęcia badań}

Coroczne wyniki badań czytelnictua nie pozostawiają wątpliwości: statystyczny Polak rzadko kiedy sięga do książek. Dane Biblioteki Narodowej uskazują, że poziom czytelnictua utrzymuje się na stałym, niskim poziomie. W 2018 roku przeczytanie co najmniej jednej książki zadeklarowało 37\% respondentów ${ }^{1}$. Innymi słowy - większość Polaków nie ma kontaktu ze słowem pisanym albo - co mniej prawdopodobne - ukrywa ten fakt przed ankieterami. Poziom czytelnictua można uznać za jedną z determinant kształtujących rynek księgarski. Mizerne wyniki, o których mowa, pozwalają sądzić, że rodzimy rynek, to rynek dla wydawcy, pisarza raczej trudny przez uzgląd na ograniczony popyt. Rośnie zatem rola komunikacji z potencjalnymi czytelnikami, których trzeba zachęcić nie tylko do samej lektury książki, ale także jej zakupu. Tu znaczenie ma między innymi dobór właściuych kanałów komunikacji, ale także ich umiejętne wykorzystanie.

Wydawcy, jak i sami autorzy nie stronią od wykorzystywania w komunikacji nowych mediów, czyli mediów cyfrowych bazujących na durustronnej komunikacji i uspóluczestnictwie w tworzeniu treści ${ }^{2}$. Za największe medium społecznościoue uchodzi Facebook - ten poustały w 2004 roku serwis społecznościouy przyciągnął do siebie ponad dwa miliardy użytkowników ${ }^{3}$. Mimo licznych kontrowersji, jakie budzi platforma Marka Zuckerberga (związanych chociażby z aferą Cambridge Analityca), serwis ciągle się rozwija - liczba jego użytkouników nadal rośnie ${ }^{4}$. Facebook można postrzegać więc nie tylko jako narzędzie komunikacji dalekiego zasięgu, ale także jako instrument promocji czytelnictua.

Niewykluczone, że to właśnie przemyślana komunikacja medialna i promocyjna stoi za sukcesem opowieści o zbrodniach; należy odnotować bowiem, że na półkach rodzimych księgarń dość dobrze radzą sobie kryminały, zaróuno polskie, jak i zagraniczne: ich popularność odzwierciedla się w wynikach sprzedaży - na liście na przykład bestsellerów Empiku łatuo znaleźć tytuły należące do tego gatunku5. Wśród twórców kryminałów szczególną uwagę czytelników, ale też znawców kultury

\footnotetext{
${ }^{1}$ Raport: Stan czytelnictwa w Polsce 2018, https://www.bn.org.pl/tag-czytelnictwo (dostęp: 08.09.2019).

2 J. Kreft, Za fasada społeczności. Elementy zarządzania nowymi mediami, Wydaunictwo Uniwersytetu Jagiellońskiego, Kraków 2015, s. 35.

${ }_{3}^{3}$ S. Vaidhyanathan, Anti-social media. Jak Facebook oddala nas od siebie i zagraża demokracji, Wydawnictwo W.A.B., Warszawa 2018, s. 2-51.

${ }^{4}$ http://wuw.proto.pl/aktualnosci/liczba-uzytkounikow-facebooka-zwieksza-sie-mimo-skandali (dostęp: 08.09.2019).

${ }^{5}$ Rankingi Empiku: https://wuw.empik.com/bestsellery/ksiazki?sort=orderRankDesc (dostęp: 08.09.2019).
} 
i mediów przykuwa, niezwykle aktywny pisarsko, Remigiusz Mróz ${ }^{6}$. Jednakże na tym pisarzu lista znanych autorów się nie kończy. Okazuje się bowiem, że na pozornie zmaskulinizowanym polu literackim sukcesy odnoszą także pisarki, takie jak Katarzyna Bonda czy Katarzyna Puzyńska. Zdaniem autorki tego opracowania działalność obu kobiet róunież zasługuje na zainteresowanie badaczy.

Przesłanką do podjęcia badań opisanych w artykule była ciekawość autorki: jak w dobie inflacji informacji, spadku czytelnictwa i ekspansji mediów społecznościouych radzą sobie twórczynie kryminałów? W jaki sposób wykorzystują nowe medium (Facebook) do promocji - jakby na to nie patrzeć - medium starego (książi)? W dalszej części pracy autorka referuje stan badań w interesującej ją dziedzinie (nowe media, komunikacja z fanami), zarysouruje syluetki pisarek, opisuje założenia metodologiczne przeprowadzonych badań i dzieli się ich wynikami, a także unioskami z nich płynącymi.

\section{Aktualny stan badań}

Wielowymiarouy charakter nowych mediów, do których należy Facebook, znajduje odzwierciedlenie u liczbie i różnorodności publikacji naukowych na ich temat. Odwołując się tu do modelu komunikowania Harolda Laswella, można dostrzec, że badania w tym zakresie poszukują odpowiedzi na pytania stawiane przez model aktu perswazyjnego (kto? co? jakim kanałem? do kogo? z jakim skutkiem?)? . Analizie poddaje się na przykład syluetki i intencje nadawców, wybór kanałów, jakimi się posługują, treść publikacji, profil psychograficzny audytorium, a także - co zazuyczaj najtrudniejsze - efekty prowadzonych działań.

Dzięki tym wysiłkom wiadomo już na przykład, że większość młodych Amerykanów urodzonych po 1995 roku korzysta z mediów społecznościouych znacznie częściej niż z innych mediów, a - jak pokazują badania - wzrost zainteresowania nowymi mediami koreluje ze spadkiem czytelnictua. Co ciekawe, stuierdzono, że nastolatki, które codziennie odwiedzają portale społecznościowe, częściej zgadzają się ze stuierdzeniami, takimi jak „często czuję się samotny”. Możliwe, że jest to pokłosie innej, raportowanej przez badaczy, cechy charakteryzującej wykorzystanie nowych mediów: otóż na Facebooku dominują duie strategie autoprezentacji - użytkounicy albo ostentacyjnie obnażają się bez granic, albo dokonują idealizacji swojego wizerunku, starannie selekcjonując zamieszczane informacje $9^{9}$. Troska o sieciouy wizerunek jest aktyunością podejmowaną

\footnotetext{
${ }^{6}$ K. Kaczor, Nazywam się Mróz. Remigiusz Mróz. O kreacji marki autorskiej/literackiej w polskim polu literackim/kultury, „Media, Biznes, Kultura” 2019, nr 1, s. 71-80.

7 T. Goban-Klas, Media i komunikowanie masowe, Wydawnictwo Naukowe PWN, Warszawa 2004.

8 J.M. Tuenge, iGen, 2019, Sopot, Smak Słowa, s. 59-80.

9 Y. Zhang, L. Shing-Tung Tang, L. Leung, Gratifications, collective self-esteem, online emotional openness, and traitlike communication apprehension as predictors of facebook uses, „Cyberpsychology, Behaviour, and Social Networking” 2011, nr 14, 12, s. 736. Cyt. za: Z. Melosik, Facebook i społeczne konstrukcje narcyzmu (o tożsamości zamkniętej $w$ celi wizerunku), „Studia Edukacyjne” 2013, nr 26.
} 
nie tylko przez przeciętnych użytkouników, ale także przez przedsiębiorstua czy osoby pouszechnie znane - nie brak publikacji naukowych czy branżouych, które wskazują na skuteczność Facebooka w zakresie komunikacji marketingowej czy wizerunkowej ${ }^{10}$.

Co kluczowe w kontekście tego artykułu, Facebook jest uskazywany także jako narzędzie przydatne $w$ zakresie stymulowania zaangażowania odbiorców, australijscy badacze dowiedli na przykład, że facebookowe profile tytułów prasouych nie tylko zuiększają zaangażowanie czytelników, ale także pielęgnują i wzmacniają świadomość marek $^{11}$. Ponadto dowiedziono, że Facebook może pełnić pozytyuną rolę, jeśli chodzi o angażowanie fanów zgromadzonych wokół drużyn sportowych ${ }^{12}$.

Należy przy tym zauważyć, że komunikacja pisarzy w mediach społecznościouych to temat wciąż czekający na zainteresowanie i pogłębioną analizę o charakterze naukowym $^{13}$. Trudno bowiem zakładać, że omawiane badania można odnieść bezpośrednio do komunikowania, jakie zachodzi na linii pisarze-fani; można jedynie wysuwać pewne przypuszczenia. Niniejsze badanie stanowi skromną próbę zmniejszenia tej luki informacyjnej.

\section{Sylwetki pisarek}

Katarzyna Bonda urodziła się u 1977 roku w Białymstoku, jest z wykształcenia dziennikarką i jakiś czas pracowała $w$ tym zawodzie ${ }^{14}$. W wywiadzie udzielonym portalowi gazeta.pl uskazywała, że jako żurnalistka potrafi „rozmawiać i słuchać” ludzi, co jest pomocne przy dokonywaniu researchu do książek ${ }^{15}$. Bonda, nie bez podstaw, określa się mianem „najpopularniejszej autorki powieści kryminalnych w Polsce”, deklarując, że uszystkie jej książki stały się bestsellerami. Szczególną popularność i wiele nagród przyniosła jej seria publikacji o przygodach profilerki Saszy Załuskiej - w ramach tetralogii ukazał się: „Pochłaniacz”, „Okularnik”, „Lampiony” oraz „Czerwony Pająk”. Co ważne, prawa do wydań zagranicznych zostały kupione już przez kilkanaście krajów $^{16}$. Katarzyna Bonda jest aktywna na trzech platformach społecznościouych:

10 J. Tkaczyk, Facebook jako narzędzie WOM marketingu, „Ekonomiczne Problemy Usług” 2011, nr 72, s. 389-399.

11 A. Aaty, S.A. Abdelkader, S. Koshy, The use of Facebook as a customer engagement tool by newspapers in the UAE: an exploratory study, „Journal of Media and Mass Communication” 2015, nr 2, s. 90-96.

${ }_{12}$ M. Meng, C. Stavros, K. Westberg, Engaging fans through social media: Implications for team identification. „Sport, Business and Management: An International Journal” 2015, nr 5, s. 199-217.

${ }^{13} \mathrm{~W}$ sieci nie brak bowiem opracowań o charakterze publicystycznym w tym zakresie: np. https://wuw.spidersweb.pl/2016/11/pisarz-na-facebooku.html (dostęp: 12.11.2019).

${ }_{14}$ Oficjalna strona Autorki: http://katarzynabonda.pl/o-autorce/ (dostęp: 08.09.2019).

${ }^{15}$ K. Cieślik, Katarzyna Bonda, Nie interesował mnie problem „żotnierzy wyklętych", ale to, jak on nas dziś infekuje, gazeta.pl, http://weekend.gazeta.pl/weekend/1,152121,18327598,katarzyna-bonda-w-takiej-sytuacji-juz-nie-wiesz-kim-jestes.html (dostęp: 08.09.2019).

${ }^{16}$ Oficjalna strona autorki: http://katarzynabonda.pl/o-autorce/ (dostęp: 08.09.2019). 
Facebooku $^{17}$, Instagramie ${ }^{18}$ oraz Twitterze ${ }^{19}$. Co istotne w kontekście prezentowanych badań, facebookouy profil pisarki śledzi ponad 46 tysięcy osób ${ }^{20}$.

Katarzyna Puzyńska urodziła się w 1985 roku i jest z wykształcenia psychologiem. Początkowo pracowała w zawodzie jako nauczyciel akademicki. Później - jak sama opisuje - postanowiła „skupić się na swojej największej pasji, czyli pisaniu”"21. Księgarski debiut Puzyńskiej, a jednocześnie pieruszy tom sagi kryminalnej o policjantach z Lipowa - „Motylek” - okazał się sprzedażowym sukcesem, niejako torując drogę kolejnym publikacjom. Prawa do tłumaczenia książek zostały sprzedane do kilkunastu różnych krajów, na przykład Austrii czy Dominikany, zdobyły też kilkanaście nagród i uyróżnień, czeka je także ekranizacja ${ }^{22}$. Autorka posiada konto na Facebooku ${ }^{23}$ oraz Instagramie ${ }^{24}$. Facebookouy profil Puzyńskiej śledzi ponad 50 tysięcy fanów.

\section{Założenia metodologiczne}

Przedmiotem opisanych w artykule badań jest aktywność pisarek: Katarzyny Puzyńskiej oraz Katarzyny Bondy na medium społecznościouym Facebook. Precyzując, autorkę interesowały zamieszczone przez pisarki posty oraz ewentualna interakcja z fanami (duukierunkowość komunikacji stanowi istotną cechę uyróżniającą nowe media ${ }^{25}$ ). Zakres czasouy badania objął lipiec i sierpień 2019, czyli okres letni oraz wakacyjny, który wydaje się dobrą okazją do przyciągnięcia urlopujących czytelników ${ }^{26}$. Warto zauważyć, że były to także miesiące poprzedzające premiery książek obu twórczyń.

Przeprowadzone badanie miało charakter niereaktyuny, jakościoury oraz ilościouy i polegało na analizie treści oraz analizie danych ${ }^{27}$. Proces badawczy składał się z trzech etapów:

- zaprojektowania badania (w tym m.in. identyfikacji profili pisarek, doboru metodologii);

${ }_{17}$ Oficjalny profil: https://web.facebook.com/katarzyna.bonda/?fref=ts (dostęp: 08.09.2019).

${ }^{18}$ Oficjalny profil: https://www.instagram.com/katarzynabonda/ (dostęp: 08.09.2019).

${ }_{19}$ Oficjalny profil: https://twitter.com/BondaKatarzyna (dostęp: 08.09.2019).

${ }^{20}$ Ibidem.

${ }^{21}$ Oficjalna strona autorki: http://www.katarzynapuzynska.pl/o-mnie1/biogram (dostęp: 08.09.2019).

${ }^{22}$ Oficjalna strona autorki: http://www.katarzynapuzynska.pl/english/awards-and-nominations (dostęp: 08.09.2019).

${ }^{23}$ Oficjalny profil: https://www.facebook.com/katarzynapuzynska (dostęp: 08.09.2019).

${ }^{24}$ Oficjalny profil: https://www.instagram.com/puzynska/ (dostęp: 08.09.2019).

25 J. Kreft, Za fasada społeczności. Elementy zarządzania nowymi mediami, Wydawnictuo Uniwersytetu Jagiellońskiego, Kraków 2015, s. 35.

${ }^{26}$ Warto zurócić uwagę, że u okresie letnim pojawia się sporo rankingów i rekomendacji związanych z lekturami na wakacje: https://polskatimes.pl/30-najlepszych-ksiazek-na-lato-i-wakacje-2019-te-powiesci-nie-zanudza-podczas-urlopu/ar/c13-14260945 (dostęp: 08.09.2019).

${ }^{27}$ E. Babbie, Badania społeczne w praktyce, Wydawnictwo Naukowe PWN, Warszawa 2019, s. 340-397. 
- zbierania i kodowania danych (narzędziem badawczym był w tym przypadku arkusz kalkulacyjny);

- analizy danych (jakościouej oraz ilościowej).

Należy dodać, że autorka zbierała i kodowała posty, które były aktywne w sieci przez minimum 7 dni: tempo przyrostu (a przez to także starzenia się) danych jest obecnie niezuykle szybkie, średni żywot „contentu” na Facebooku specjaliści oceniają na 5 godzin $^{28}$. Oznacza to, że w ciągu 7 dni posty powinny wywołać maksymalną dla nich liczbę reakcji. Celem podjętych badań były opis i analiza aktyuności pisarek na Facebooku, a także uzyskanie odpowiedzi na pytania badaucze zamieszczone w tabeli 1.

Tabela 1. Pytania badaucze

\begin{tabular}{|l|l|}
\hline Pytania badawcze (ilościowe) & Pytania badaucze (jakościoue) \\
\hline (1) Jak często autorki publikują posty? & (4) Jakie treści publikują autorki? \\
\hline $\begin{array}{l}\text { (2) Jak często stosują wezwanie do akcji/działania } \\
\text { (CTA, call-to-action)? Czy upływa to pozytyunie na } \\
\text { liczbę reakcji? }\end{array}$ & $\begin{array}{l}\text { (5) Czy wchodzą w interakcje z fanami? W jaki } \\
\text { sposób? }\end{array}$ \\
\hline $\begin{array}{l}\text { (3) Jakie wyniki osiągają posty autorek? (jeśli chodzi } \\
\text { o liczbę reakcji fanów) }\end{array}$ & $\begin{array}{l}\text { (6) Czy w ramach postów można wyodrębnić jakieś } \\
\text { grupy? Jeśli tak, to jakie? }\end{array}$ \\
\hline
\end{tabular}

Warto zaznaczyć, że za „wzywające do akcji” publikacje autorka uznała posty, które albo zawierały pytanie, na przykład „Co sądzicie o...?”, albo wprost nawoływały do aktyuności: „Dajcie znać”. Poprzez „wchodzenie w interakcję z fanami” autorka rozumiała reakcję pisarek na komentarze czytelników, niezależnie od tego, czy chodziło przykładowo o lajki ze strony pisarek, czy też odpowiedzi na komentarze. Przez uzgląd na objętość materiału badawczego interakcja z fanami została zbadana na próbie 10 losouych postów każdej z pisarek ${ }^{29}$.

W toku badań postanowiono zweryfikować dwie hipotezy badawcze: po pierwsze, założono, że „wezwanie do akcji” ze strony Katarzyny Bondy czy Katarzyny Puzyńskiej będzie pozytyunie upływało na liczbę reakcji ze strony publiczności. Po drugie, przyjęto, że obie pisarki będą dodawać posty z podobną częstotliwością.

Ze względu na złożony charakter badań ich wyniki zostaną zaprezentowane z podziałem na ich ilościouy oraz jakościouy charakter.

\section{llościowe wyniki badań}

Już pierusze wyniki badań ilościowych wywołały zaskoczenie autorki: okazało się bowiem, że okres wakacyjny był bardzo intensyuny pod kątem publikacji tylko dla jednej z pisarek. Różnica w liczbie i częstotliwości publikowanych postów jest więcej

\footnotetext{
${ }^{28}$ Więcej na ten temat: https://wuw.skyword.com/contentstandard/marketing/hou-long-does-your-content-last-online-data/ (dostęp: 09.09.2019).

${ }_{29}$ Wszystkie zakodowane posty stanowiły zatem populację, z której uylosowano 10 postów poddanych głębszej analizie.
} 
niż zauważalna: przez wakacje Katarzyna Puzyńska zaprezentowała w sumie 89 postów, harmonogram publikacji układał się w regularny schemat: Puzyńska publikowała każdego dnia jeden do dwóch postów. Z kolei Katarzyna Bonda opublikouała w tym czasie 15 postów, które pojawiały się ze zmienną częstotliwością, z przerwami, zułaszcza w sierpniu ${ }^{30}$.

Przeciętny post Puzyńskiej otrzymywał 904 reakcje (lajki, serduszka i inne ${ }^{31}$ ), 169 komentarzy i 4 udostępnienia. W przypadku Bondy liczby te wynosiły odpowiednio: 802, 155 oraz 6. Można zaryzykować stuierdzenie, że choć pisarki mocno różniły się w zakresie intensyuności publikacji, reakcje ich fanów można uznać za zbliżone, choć trochę lepsze w przypadku aktywniejszej Puzyńskiej.

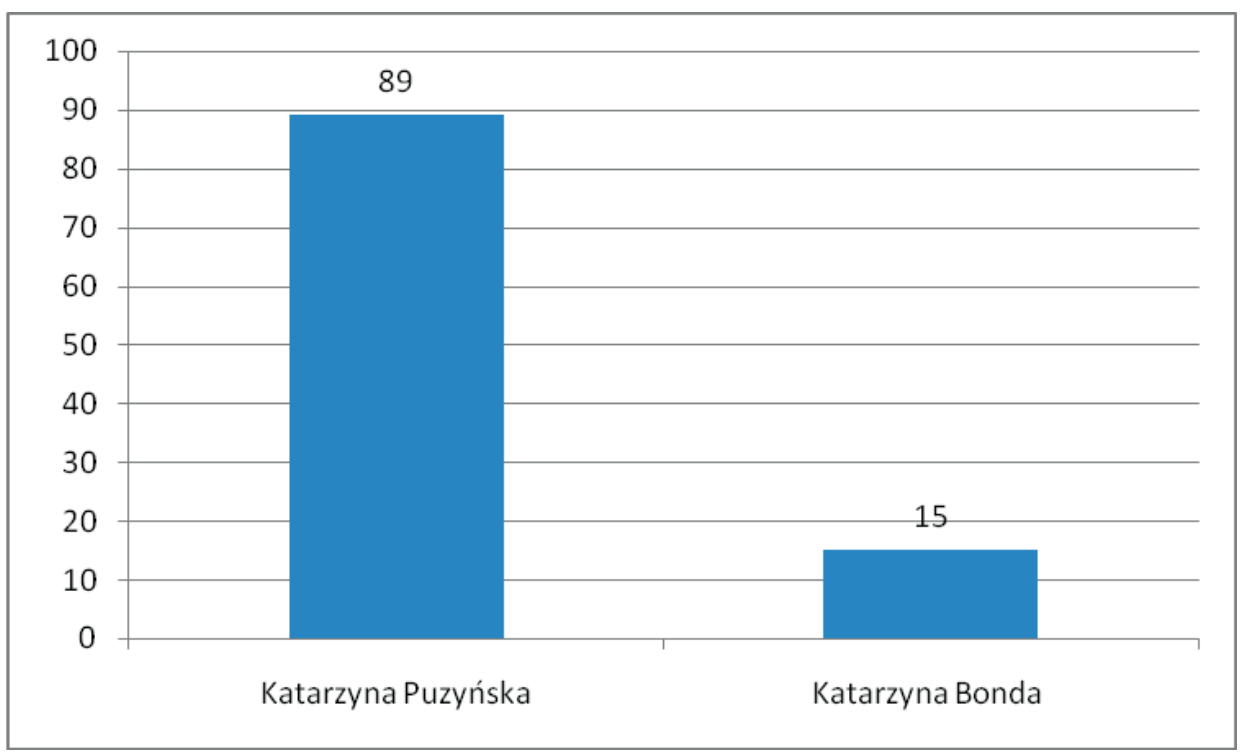

Rycina 1. Liczba postów opublikowanych na FB przez pisarki (07-08.2019)

Źródło: wyniki badań własnych prowadzonych od lipca do września 2019 roku.

Jeśli chodzi o „wezwania do akcji” (CTA), to Puzyńska zastosowała je prawie w połowie wszystkich postów (40 na 89 postów), natomiast Bonda zdecydowała się na to tylko dua razy (2 na 15 postów). Wynika z tego, że Puzyńska znacznie częściej (zarówno w liczbach względnych, jak i bezwzględnych) sięgała po „wezwania do akcji”, pytając na przykład: „Co u Was?”32.

\footnotetext{
30 Źródło: wyniki badań własnych profili, lipiec-sierpień 2019.

${ }^{31}$ Pełną paletę reakcji można zobaczyć tutaj: https://pl-pl.facebook.com/business/help/11865 4155244100?helpref=faq_content (dostęp: 24.09.2019).

${ }^{32}$ Post autorki: https://wuw.facebook.com/katarzynapuzynska/photos/a.247887355420494/1115 409402001614/?type=3\&_xts_\%5B0\%5D=68.ARDy9ShDy0Wk2deqeyOwVakp7CCqjqzcXOmNbSTOB8QBvvIppVrSVV2VlKjGr5AgICnR1V8JlBdzUqyVsZamohPHJfF1VRW3O6eVGTbQVhWKZhDyM9 (dostęp: 09.09.2019).
} 
Czy „wezwania do akcji” miały upływ na reakcje publiczności? Aby to sprawdzić, autorka najpierw pogrupowała publikacje na dwie grupy: pierusza z nich agregowała posty zakodowane jako zawierające „wezwanie”; druga agregowała posty zakodowane jako „bez wezwania”. W ramach tych grup prowadzono dalsze obliczenia tak, aby sprawdzić, ile średnio reakcji, komentarzy i udostępnień generują posty z obu grup. Uzyskane wyniki zaprezentowano w tabeli 2.

Tabela 2. Średnia liczba reakcji na posty „z wezwaniem” oraz „bez wezwania”

\begin{tabular}{|l|c|c|}
\hline & Posty z „wezuaniem” & Posty „,bez wezwania” \\
\hline Katarzyna Bonda & 570 & 837 \\
\hline Reakcje (łącznie) & 140 & 157 \\
\hline Komentarze & 8 & 6 \\
\hline Udostępnienia & 761 & 1021 \\
\hline \multicolumn{2}{|c|}{} \\
\hline Katarzyna Puzyńska & 210 & 136 \\
\hline Reakcje (łącznie) & 3 & 5 \\
\hline Komentarze & &
\end{tabular}

Źródło: wyniki badań własnych prowadzonych od lipca do urześnia 2019.

Okazało się, że „wezwania do akcji” prawdopodobnie nie są czynnikiem specjalnie motyuującym publikę pisarek do aktyuności. Należy przy tym zaznaczyć, że u przypadku Katarzyny Bondy do wyników trzeba podejść z dużą ostrożnością, w wakacje ukazało się zasadniczo niewiele postów, tylko dwa z nich zawierały wezwanie. Na bazie tak skromnej próby, nieporozumieniem byłoby wyciąganie jednoznacznych wniosków. Ostrożne konkluzje można natomiast formułować na podstawie wyników osiąganych przez posty Katarzyny Puzyńskiej. Dane pokazują zmienną korelację między wezwaniem a liczbą reakcji: wezwanie zuiększyło średnią liczbę komentarzy, ale nie zadziałało w przypadku reakcji, czy tak cennych w mediach społecznościouych udostępnień. Wynika z tego, że to niekoniecznie wezwania bądź ich brak odgrywają kluczową rolę, jeśli chodzi o popularność postów.

Aby odpowiedzieć na pytanie, co motyuuje fanów do reakcji na posty, warto zurócić uwagę na te publikacje, które cieszyły się szczególnie dużą popularnością. W przypadku Katarzyny Bondy najbardziej lajkowanym ${ }^{33}$, udostępnianym oraz komentowanym postem był ten, w którym podzieliła się ona informacją o swoich urodzinach: „Dziś mam urodziny! Pesel uyraźnie uskazuje, że skończyłam 42 lata, ale wciąż jeszcze nie nauczyłam się zachouyuać jak na dorosłą panią przystało (to chyba nigdy nie nastąpi:) (...)" ${ }^{\prime 34}$. Publikacja ta zdobyła 3200 reakcji, wygenerowała 894 komentarze, zdobywając przy okazji 27 udostępnień. Popularność tego postu mocno dystansowała inne publikacje autorki (co jest widoczne jest, jeśli porównać te wyniki z liczbami z tabeli 1).

\footnotetext{
${ }^{33}$ Pisząc lajkowanym, autorka stosuje skrót myślouy, gdyż ma na uwadze uszystkie reakcje, jakie w panelu użytkownika ma do uyboru odbiorca postu.

${ }_{34}$ Post autorki: https://wuw.facebook.com/katarzyna.bonda/photos/a.229489056326/10157222 666461327/?type=3\&theater (dostęp: 09.09.2019).
} 
W przypadku Katarzyny Puzyńskiej najchętniej udostępniany (54) i lajkowany (3500) był ostatni wakacyjny wpis o bardzo osobistym charakterze: autorka dzieliła się $\mathrm{w}$ nim informacją na temat przebytej choroby i jej związku z posiadanymi tatuażami ${ }^{35}$. Najwięcej komentarzy natomiast (754) wzbudził inny osobisty post, który nie miał już tak dramatycznego uydźwięku - autorka prosiła u nim o poradę dotyczącą stroju: „Pomocy! Jutro muszę być nieco bardziej formalnie ubrana niż zazwyczaj. Ale! Niezbyt się na tym znam. Która marynarka lepsza?"36. Zreferowane tutaj wyniki badań ilościouych pozwalają przypuszczać, że osobiste posty autorek mają dość duży potencjał, jeśli chodzi o wywoływanie reakcji fanów. Wezwania do akcji zdają się mieć pośledniejsze znaczenie.

\section{Jakościowe wyniki badań}

Zarówno Katarzyna Bonda, jak i Katarzyna Puzyńska publikowały prawie wyłącznie proste posty składające się ze zdjęcia oraz podpisu, stroniąc od publikowania filmików, dużych galerii zdjęć czy transmisji na żywo. Na tym kończą się zasadnicze podobieństua, a zaczynają różnice.

Katarzyna Bonda publikowała (choć nie była u tym konsekwentna) wpisy duujęzyczne - po polsku i po angielsku, zuracając się do publiczności per: „Państwo”, na przykład: „Może utedy zrobię tutaj jakiś konkurs dla chętnych:) Czy Państwo byliby zainteresowani?:)"37. Oficjalna apostrofa przełamana została jednak samą, dość potoczną, żywą treścią postów, a także licznymi emotikonami stosowanymi przez pisarkę. Każdy wpis Bondy kończyło pozdrowienie oraz podpis (por. zdjęcie 1).

Zdjęcia zamieszczane przez Autorkę u znakomitej większości przypadków prezentowały ją samą w różnych kontekstach. Fani mogli zatem zobaczyć pisarkę odbierającą kuiaty od wydawcy ${ }^{38}$, jak i uypoczywającą na plaży ${ }^{39}$. Wśród zamieszczonych przez Bondę publikacji można uyodrębnić zasadniczo dua rodzaje postów: po pierusze, posty promujące czy też zapowiadające nowe książki (zwłaszcza uydania obcojęzyczne), po drugie, posty osobiste, czyli takie, które były skupione raczej na postaci autorki i miały różnorodny charakter: Autorka opowiadała w nich o swojej pracy ${ }^{40}$, zdradzała

\footnotetext{
35 Post autorki: (dostęp: 09.09.2019).

${ }^{36}$ Post autorki: https://www.facebook.com/katarzynapuzynska/photos/a.247887355420494/110 0107256865162/?type=3\&theater (dostęp: 09.09.2019).

37 Post autorki: https://wuw.facebook.com/katarzyna.bonda/photos/a.229489056326/10157104 212906327/?type=3\&_tn__=-R (dostęp: 09.09.2019).

${ }_{38}$ Post autorki: https://wuw.facebook.com/katarzyna.bonda/photos/a.229489056326/101571087 31696327/?type=3\&theater (dostęp: 09.09.2019).

${ }^{39}$ Post autorki: https://wuw.facebook.com/katarzyna.bonda/photos/a.10152376627101327/101 57172915681327/?type=3\&_tn_=-R (dostęp: 09.09.2019).

${ }^{40}$ Post autorki: https://wuw.facebook.com/katarzyna.bonda/photos/a.229489056326/10157095 883616327/?type=3\&theater (dostęp: 09.09.2019).
} 
upodobania czytelnicze ${ }^{41}$ bądź datę swoich urodzin ${ }^{42}$. Do pieruszej kategorii można zaliczyć 8 postów, do drugiej zaś 7 publikacji.

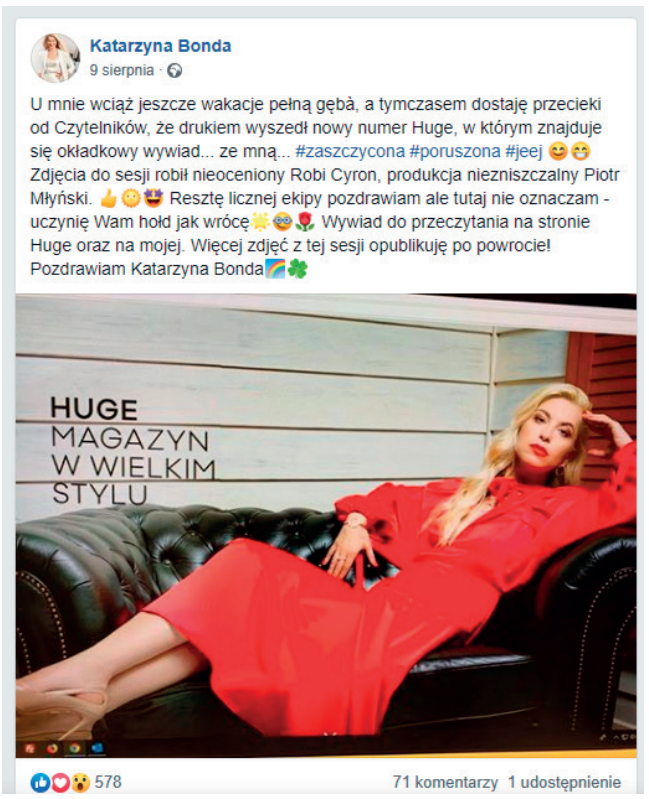

Zdjęcie 1. Przykładouy post Katarzyny Bondy

Źródło: Facebook Katarzyny Bondy: https://www.facebook.com/katarzyna.bonda/photos/a.1015237 6627101327/10157180003816327/ ?type=3\&_tn__=-R (dostęp: 09.09.2019).

Bonda nie pozostawała obojętna na komentarze fanów - pisarka wchodziła z nimi w interakcje, które przyjmowały postać reakcji (np. lajków) bądź komentarzy. Responsyuność Bondy była widoczna zułaszcza w poście, w którym ogłaszała konkurs na najlepsze komentarze, będące odpowiedzią na pytanie: „Czego szukam w opowieści, co mnie porywa, nie daje odłożyć książki v/s co mnie drażni u zapisie, czego nie cierpię?"43. Pisarka dziękowała praktycznie za każdy wpis, tworząc nieraz całkiem długie, bezpośrednie odpowiedzi (por. zdjęcie 2).

Co ciekawe, większość komentujących odzuierciedlała styl komunikacji pisarki: fani zuracali się do niej per: „Pani Kasiu”, skracając jednak dystans treścią komentarzy oraz emotikonami. Serdeczność łącząca Bondę i czytelnikóu była jedną z głównych cech wyróżniających ich komunikację.

${ }_{41}$ Post autorki https://wuw.facebook.com/katarzyna.bonda/photos/a.229489056326/101572302 35226327/?type=3\&theater (dostęp: 09.09.2019).

${ }^{42}$ Post autorki: https://wuw.facebook.com/katarzyna.bonda/photos/a.229489056326/101572226 66461327/?type=3\&theater (dostęp: 09.09.2019).

${ }^{43}$ Post autorki: https://wuw.facebook.com/katarzyna.bonda/photos/a.229489056326/10157147 780366327/?type=3\&_tn__=-R (dostęp: 09.09.2019). 
५ Wyświetl 1 dodatkową odpowiedź

Marta W książkach najczęściej szukam nieszablonowych

bohaterów z ciekawą historią, lubiẹ też gdy w książce pojawiają sie jakieś śmieszne fragmenty, które bawią do łez i rozładowuja

atmosfere (chociaż na chwilke). Coś co mnie od ksiażek odpycha to

zdecydowanie długie opisy i nagle pojawiające się nierealne

sytuacje, które w rzeczywistości nie miałyby prawa się zdarzyć.

Bardzo chętnie przygarnę „Okularnika”, ponieważ „Pochłaniacz" już

przeczytałam

$6 \mathrm{t}$ - Edytowano

Wybrano tryb sortowania Najtrafniejsze, więc niektóre odpowiedzi mogły zostać pominięte w wyniku filtrowania.

9 Katarzyna Bonda Ja też uwielbiam śmiać się w głos w trakcie lektury. To rodzi czasem konfuzję, kiedy się jest w miejscu publicznym. To jednak takie intymne:) Pamietam jak czytałam w samolocie książkẹ i rechotałam nieustannie. Kiedy skończyłam pan siedzący obok poprosił, żebym mu ją sprezentowała, co też uczyniłam:)

$6 \mathrm{t}$

$\hookrightarrow$ Wyświetl 1 dodatkową odpowiedź

Zdjęcie 2: Przykładowa interakcja z fanami

Źródło: Facebook Katarzyny Bondy: https://www.facebook.com/katarzyna.bonda/photos/a.2294890 56326/10157147780366327/?type=3\&_tn__=-R (dostęp: 09.09.2019).

Profil Katarzyny Puzyńskiej jest prowadzony w języku polskim; w okresie poddanym badaniom autorka prezentowała bezpośredni, swobodny styl komunikacji, zuracając się do suoich fanów na „ty”; „Dostałam od Was link, gdzie można zobaczyć nagranie mojej dzisiejszej wizyty u Dzień Dobry TVN" "44. Pisarka chętnie i często wchodziła w interakcje z fanami, stosując reakcje bądź zazuyczaj krótkie, bazujące na emotikonach, komentarze. Fani zuracali się do Puzyńskiej u sposób bardziej („Pani Kasiu”) lub mniej („Kasiu”) oficjalny. Podobnie jak było w przypadku Katarzyny Bondy, komunikacja z fanami miała przyjazny, pełen życzliwości charakter (por. zdjęcie 3).

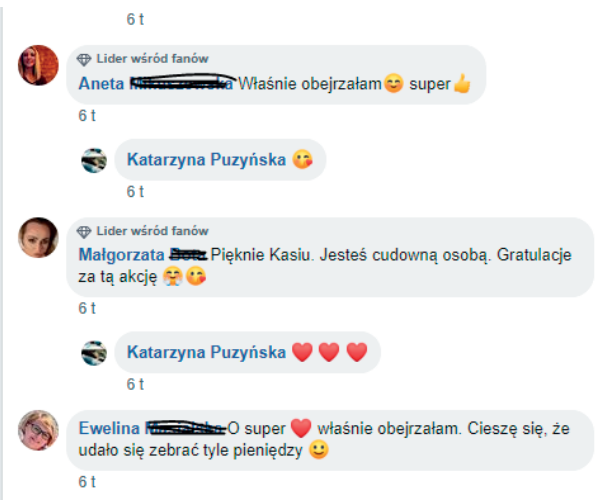

Zdjęcie 3. Przykładowa interakcja z fanami

Źródło: Facebook Katarzyny Puzyńskiej: https://wuw.facebook.com/katarzynapuzynska/photos/a.24 7887355420494/1108200806055807/?type=3\&_tn__=-R (dostęp: 09.09.2019).

${ }_{44}$ Post autorki: https://wuw.facebook.com/katarzynapuzynska/photos/a.247887355420494/110 8200806055807/?type=3\&_tn__=-R (dostęp: 09.09.2019). 
Dość obszerny materiał badauczy krył w sobie gamę różnotematycznych postów: Puzyńska publikowała informacje związane z promocją książek, ale sporo uwagi poświęciła też prowadzonej przez nią akcji charytatyunej na rzecz wdów i sierot po poległych policjantach ${ }^{45}$. Autorka chętnie dzieliła się też zdjęciami swoich psów ${ }^{46}$ czy informowała o zrobieniu kolejnych tatuaży ${ }^{47}$. Stałe miejsce na profilu miała też miejscowość, u której mieszka pisarka i której rozgrywa się też akcja serii książek o „Policjantach z Lipowa”: autorka dzieliła się z fanami kolorowymi krajobrazami ${ }^{48}$, a także migawkami z własnego, nowo powstałego domu (por. zdjęcie 4).

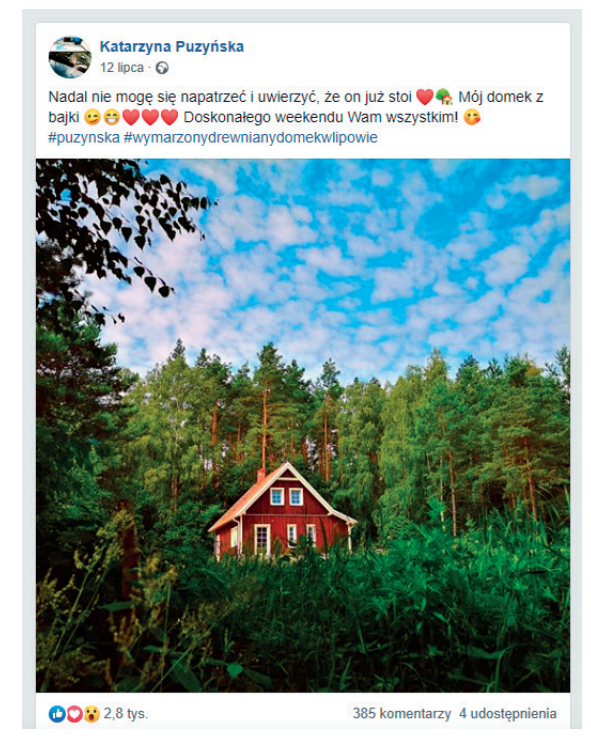

Zdjęcie 4. Post o nowym domu

Źródło: Facebook Katarzyny Puzyńskiej: https://wuw.facebook.com/katarzynapuzynska/photos/a.24 7887355420494/1097328833809671/?type=3\&_tn__=-R (dostęp: 09.09.2019).

Mimo całej różnorodności, posty Puzyńskiej można podzielić na cztery grupy:

- autoportrety - czyli posty zawierające zdjęcia autorki w różnych okolicznościach i w różnym towarzystwie (tu można wyróżnić zdjęcia z samą Puzyńską, zdjęcia w towarzystwie ludzi, zdjęcia w towarzystwie psów oraz zdjęcia prezentujące tylko „fragmenty” pisarki, np. dłoń z tatuażami); zidentyfikowano 46 postów wpisujących się do tej kategorii;

$\overline{45}$ Post autorki: https://wuw.facebook.com/katarzynapuzynska/photos/a.247887355420494/109 7871660422055/?type=3\&_tn__=-R (dostęp: 09.09.2019).

${ }^{46}$ Post autorki: https://wuw.facebook.com/katarzynapuzynska/photos/a.247887355420494/109 4480577427830/?type=3\&_tn__=-R (dostęp: 09.09.2019).

${ }_{47}$ Post autorki https://wuw.facebook.com/katarzynapuzynska/photos/a.247887355420494/109 4834094059145/?type=3\&_tn__=-R (dostęp: 09.09.2019).

${ }^{48}$ Post autorki: https://wuw.facebook.com/katarzynapuzynska/photos/a.247887355420494/109 3877794154775/?type=3\&_tn__=-R (dostęp: 09.09.2019). 
- promocje książek - czyli posty skupiające się na promocji twórczości autorki; zidentyfikowano 9 postów tego rodzaju;

- naturę (krajobrazy \& zuierzęta), czyli publikacje przedstawiające psy pisarki bądź obrazujące piękno przyrody otaczającej autorkę i korespondujące z treścią jej książek; do tej kategorii można zaliczyć 24 posty Puzyńskiej;

- inne, czyli posty, które nie wpisują się wyraźnie w żadną z tych kategorii; do tej kategorii należy 10 postów.

\section{Wnioski i dyskusja}

Na podstawie przeprowadzonych analiz można sądzić, że cel pracy, czyli opis i analiza wakacyjnej aktyuności pisarek na Facebooku, został osiągnięty. Udało się także uzyskać odpowiedź na postawione pytania badaucze.

Zaobserwowano dużą różnicę między pisarkami w zakresie częstotliwości publikowania postów. Katarzyna Puzuńska publikowała codziennie, czasem nawet dwa razy, Katarzyna Bonda publikowała średnio co cztery dni.

Obie autorki stosowały w suych postach „wezwania do akcji”, przy czym Puzyńska stosowała je prawie u co drugim poście, Bonda tylko durukrotnie. Nie stuierdzono jasnej korelacji między „wezwaniem do akcji” a liczbą różnorodnych reakcji publiczności. Można zaryzykować stwierdzenie, że „wezwania do akcji” wcale nie są tak skuteczne w angażowaniu publiczności, jak mogłoby się wydawać.

Posty Katarzyny Bondy zdobywały średnio: 802 reakcje, 155 komentarzy i 6 udostępnień. Dla postów Katarzyny Puzyńskiej te wartości wynosily odpowiednio: 904, 169 oraz $4^{49}$. Zaangażowanie fanów obu autorek można uznać za porównywalne, z lekką przewagą po stronie społeczności zgromadzonej wokół Puzyńskiej.

Katarzyna Bonda publikowała głównie posty związane z szeroko pojętą promocją książek bądź poświęcone jej osobie (co było widoczne także na zdjęciach). Katarzyna Puzyńska prezentowała szerszy wachlarz tematyczny: obok postów promocyjnych i osobistych dzieliła się między innymi zdjęciami krajobrazów, zwierząt, a nawet migawkami z koncertu Metallica ${ }^{50}$.

Obie pisarki nieustannie wchodziły $\mathrm{w}$ interakcje $\mathrm{z}$ fanami albo reagując na komentarze emotikonami albo pisząc coś od siebie. Wypowiedzi Bondy - choć wymaga to dalszych badań, były nieco dłuższe od wypowiedzi Puzyńskiej. Warto odnotować, że na profilach obu autorek panowała serdeczna, pełna wzajemnych grzeczności atmosfera. Trudno było odnaleźć tam wyrazy krytyki czy tak często utożsamiany z Internetem

\footnotetext{
49 Autorka artykułu zsumowała osobno uszystkie reakcje, komentarze i udostępnienia, a później podzieliła je przez liczbę postóu każdej z pisarek, aby spraudzić, ile reakcji przypada średnio na pojedynczego posta.

${ }^{50}$ Post autorki: https://wuw.facebook.com/katarzynapuzynska/photos/a.247887355420494/112 5281784347709/?type $=3 \& \_$tn__=-R (dostęp: 10.09.2019).
} 
hej ${ }^{51}$. Pisarki różnymi drogami skracały dystans z odbiorcami, uspółtuorząc kordialną, miejscami wręcz familiarną atmosferę i otrzymując w odpowiedzi wyrazy sympatii ze strony odbiorców.

W ramach postów Katarzyny Bondy można uyróżnić duie kategorie: posty promujące książki oraz posty osobiste. W przypadku Katarzyny Puzyńskiej można mówić o czterech kategoriach: promocjach książek, autoportretach, naturze oraz „innych”. Garnitur tematów wykorzystywanych przez Puzyńską był zatem znacznie szerszy, można rzec: eklektyczny.

Z badań można uyciągnąć trzy ostrożne unioski. Po pierusze, „wezwania do akcji” niekoniecznie przesądzają o popularności postów (przynajmniej w odniesieniu do fanów pisarek na FB). Po drugie, profile Puzyńskiej i Bondy gościły wiele przychylnych i miłych komentarzy. Autorki chętnie wchodziły w interakcje z użytkounikami. Zdaje się, że zarówno Puzyńska, jak i Bonda stworzyły wokół siebie przyjazną, wolną od hejtu społeczność (czyli coś więcej niż zuykłą „grupę fanów”). To niewątpliwie budująca i pozytyuna wiadomość ${ }^{52}$. Po trzecie, okazało się, że skromna w sensie ilościouym, nieregularna aktywność Bondy przyniosła dość podobne efekty, co intensyuna i bardziej różnorodna aktyuność Puzyńskiej (średnia liczba reakcji fanów u obu pisarek była zbliżona). Podsumouując, pewne intuicyjne przypuszczenia („CTA zwiększa zaangażowanie”), uogólnienia („Internet jako siedlisko hejtu”) czy marketingowe porady („regularny kontakt z fanami to podstawa”) nie mają charakteru bezuzględnie obowiązującego. Parafrazując słowa poetki i noblistki Wisławy Szymborskiej, można stuierdzić, że „tyle wiemy o komunikacji w nowych mediach, na ile to spraudziliśmy”.

Oczywiście, opisane w pracy badania nie mają charakteru wyczerpującego - należałoby bowiem dalej monitorować i badać aktyuność pisarek, aby móc poróunać ze sobą nie tylko postacie, ale także poszczególne pory roku: okres letni ma inną specyfikę niż na przykład okres jesienno-zimowy. Ponadto warto, aby przyszłe badania w tym zakresie uwzględniły także pozostałe profile społecznościowe kandydatek. Dzięki temu eksploracje zyskałyby szerszą perspektywę i umożliwiły wyciągnięcie pogłębionych uniosków.

\section{Bibliografia}

Aaty A. Abdelkader Saad Abdel, Koshy S., The use of Facebook as a customer engagement tool by newspapers in the UAE: an exploratory study, „Journal of Media and Mass Communication" 2015, nr 2.

Babbie E., Badania społeczne w praktyce, Wydawnictwo Naukowe PWN, Warszawa 2019.

Cieślik K., Nie interesował mnie problem „żotnierzy wyklętych”, ale to, jak on nas dziś infekuje, http://weekend.gazeta.pl/weekend/1,152121,18327598,katarzyna-bonda-w-takiej-sytuacji-juz-nie-wiesz-kim-jestes.html (dostęp: 09.09.2019).

${ }^{51}$ Choć badanie nie skupiało się na analizie wizerunków warto odnotować, że między autorkami uystępowały zarówno podobieństua (otwartość na relację z fanami), jak i różnice (np. uygląd fizyczny i sposób prezentacji siebie). 52 
Goban-Klas T., Media i komunikowanie masowe, Wydawnictwo Naukowe PWN, Warszawa 2004.

Kaczor K., Nazywam się Mróz. Remigiusz Mróz. O kreacji marki autorskiej/literackiej w polskim polu literackim/kultury, „Media, Biznes, Kultura” 2019, nr 1.

Kreft J., Za fasada spoleczności. Elementy zarządzania nowymi mediami, Wydaunictwo Uniwersytetu Jagiellońskiego, Kraków 2015.

Melosik Z., Facebook i społeczne konstrukcje narcyzmu (o tożsamości zamkniętej $w$ celi wizerunku), „Studia Edukacyjne” 2013, nr 6.

Meng M., Stavros C., Westberg K., Engaging fans through social media: Implications for team identification, „Sport, Business and Management: An International Journal” 2015, nr 5.

Oficjalna strona autorki: http://katarzynabonda.pl/o-autorce/ (dostęp: 08.09.2019).

Oficjalny profil autorki: https://web.facebook.com/katarzyna.bonda/?fref=ts (dostęp: 08.09.2019).

Oficjalny profil autorki: https://uww.instagram.com/katarzynabonda/ (dostęp: 08.09.2019).

Oficjalny profil autorki: https://twitter.com/BondaKatarzyna (dostęp: 08.09.2019).

Oficjalna strona autorki: http://www.katarzynapuzynska.pl/o-mnie1/biogram (08.09.2019).

Oficjalna strona autorki: http://www.katarzynapuzynska.pl/english/awards-and-nominations (dostęp: 08.09.2019).

Oficjalny profil: https://wuw.facebook.com/katarzynapuzynska (dostęp: 08.09.2019).

Oficjalny profil: https://www.instagram.com/puzynska/ (dostęp: 08.09.2019).

Raport: Stan czytelnictwa w Polsce 2018, https://www.bn.org.pl/tag-czytelnictuo (dostęp: 08.09.2019).

Salinas S., Liczba użytkowników Facebooka zwiększa się mimo skandali, http://www.proto.pl/ aktualnosci/liczba-uzytkounikow-facebooka-zwieksza-sie-mimo-skandali (dostęp: 10.09.2019).

Tkaczyk J., Facebook jako narzędzie WOM marketingu, „Ekonomiczne Problemy Usług” 2011, nr 72.

Twenge J.M., iGen, Smak Słowa, Sopot 2019.

Vaidhyanathan S., Anti-social media. Jak Facebook oddala nas od siebie i zagraża demokracji, Wydawnictuo W.A.B., Warszawa 2018. 